\title{
Analysis of "A Rose for Emily" from the Perspective of the Stylistic Features of Confabulation and Symbolism
}

\author{
Yan $\mathrm{Xu}$ \\ Foreign Language School \\ Huanghe Science and Technology College \\ Zhengzhou, China
}

\begin{abstract}
Fiction creation composes of confabulation and symbolism that are two important features in telling the stories. Faulkner, a famous writer in America, displays his works with the strategy of confabulation and symbolism. A Rose for Emily, being one of the most celebrated novels, is one of the typical representatives combined confabulation and symbolism. This paper aims at getting better interpretation of the literature with the analysis of the stylistic features of confabulation and symbolism.
\end{abstract}

Keywords_”A rose for Emily”; Faulkner; Symbolism; realism; odernism

\section{INTRODUCTION}

The short story "A Rose for Emily" is written by William Faulkner who was an outstanding southern writer of America. All of his works involve war, race, class, soil, and family violence. Few characters in Faulkner's works have normal sense. In the short story "A Rose for Emily", Miss Emily, the main character of the short story, is a typical one who resembles almost all the aspects of William Faulkner's writing style. In this story, Faulkner portrays a vivid picture of the southern town Jefferson of the United States.

There are three main characters who are Miss Emily, Miss Emily's father and Miss Emily's lover, Homer Barron. Miss Emily's father and Homer Barron have effect on Emily's behavior and the complexity of her mind. First of all, Emily's father is the main person who has great influence on Emily. Then, Homer Barron, the only lover in Emily's whole life and the contrast of Emily, also has influence on Emily. Finally, town's people also have effect on Emil's behavior, for some of Emily's behavior would be influence by their gossip. In the story, Emily's strange and weird behavior is not because of her nature but is because of the influence from other people. In the story, Emily's father is the most important person who led Emily's behavior and even when he was dead, Emily was still under his control. Due to the pressure that Emily's father put on her, Emily's mind and actions became weird, distorted and even somehow self-enclosed. In this way, her life was also being closed from the outside world.

The structure of the plot is the reverse order. The short story begins with Miss Emily's death, then, her life experience developed. With the development of the plot, the conflict about the life of Miss Emily is presented. At the end of the story, to everyone surprised, Homer Barron, the only lover of Miss Emily, was poisoned by Miss Emily and she had slept with his dead body for many years. Miss Emily's tragedy lies in the obstinate traditional sense of hierarchy in the Old South of America. The conflicts, between the new system in the New South during its foundation and the old system in the Old South, as well as her greatly twisted character, lead to her tragic fate.

\section{INTERPRETATION OF CONFABULATION AND SYMBOLISM}

Confabulation, deriving from Latin "fictio", is a way of creating stories according to the writer's imagination to express the writer's emotion. The works, composed by the writer, are different from the report or the historical science. Although the value of literature focuses on the truth, the truth in the literature is different from the historical science in the value orientation. However, as far as the value orientation is concerned, the realism literature and the modernist literature aim at the reflection of the terminal significance in the works sought by the writer and the critics all the time. Fiction, as one of the literary genres, reflects the real life and expresses the thought of the writers by means of the construction of the characters, the way of narrative the certain story and the description of the surroundings. In the process of composing the fictions in the realism and the modernism, the writer should obey the basic rule of using the confabulation in the fiction, although there are great different between the two styles of literature creation. It is known that the literatures focus on the fate of the characters, being the human being, so what the works should aim at is to care about the whole political surroundings where the characters lived instead of the abstract relationship of the persons.

Symbolism, a strategy of creating the literature, is used to express the certain abstract conception, thoughts and emotion by means of the concrete images. Undoubtedly, the symbolism of "A Rose for Emily" is the real goal reached by William Faulkner. In this short novel, the ruined family from the southern part of America symbolized the significant change of the social systems of the southern part in America. The writer 
employed a lot of the symbolic narrative strategy to reveal the decayed force in the south of America and therefore, symbolism becomes the theme of the short novel.

On the perspective of some scholars, the literature, based on the humanism, has the stylistic features of combining of confabulation and symbolism and shows the ideology with the way of the narrative language. Generally speaking, as far as the writer is concerned, the fictional world of the literature, especially the world in the works read by the readers, is the basic strategy employed by the writers in the process of description. As for the readers, the literature is the symbolic behavior of the society, according to the opinion of the critic named Fredric Jameson. Therefore, the combining of confabulation and symbolism is, actually, the connection of the form and the content of the literature.

"A Rose for Emily" is a confabulation, written by William Faulkner. In the short story, Emily Grierson, a fictional character, was a young unmarried woman from a rich family in the southern part of America. Although her family went bankrupt, she preserved her grave and dignified bearing. Therefore, she refused to pay tax that she should pay for. There is full of the atmosphere of the absurdity in the fictional novel in which William Faulkner led the readers to the perplexing and terrifying maze, which is a strategy used by William Faulkner and is also one of the basic features of the literature of modernism. However, with the development of the plot, the character's confusing behaviors and the inner world was revealed in the language of symbolism.

\section{ANALYSIS OF THE LITERATURE WITH THE STRATEGY OF CONFABULATION AND SYMBOLISM}

In order to get more explicit picture of this short story entitled "A Rose for Emily", the style of it can be analyzed in the light of the stylistic features of confabulation and symbolism which mainly focus on the presentation of time, place and dialogue as well as foregrounding.

As one of the devices for constructing realism in texts, the presentation of time situates the narrative in real, historical time, by referring to events that actually took place, ranging from the very specific to more general references to a given historical period. For instance, in part I, "Alive, Miss Emily had been a tradition, a duty, and a care; a sort of hereditary obligation upon the town, dating from that day in 1894 when Colonel Sartoris, the mayor-he who fathered the edict that no Negro woman should appear on the streets without an apronremitted her taxes, the dispensation dating from the death of her father on into perpetuity." From this selected text, the word "alive" indicates the period in which Miss Emily lived and the following description of life experience of Miss Emily is situated within a particular historical time. It is transparent for readers to know about the specific time of the event. Another sign which shows the specific time is 1894.1894 is at the end of nineteenth-century in which the old traditional system was popular in America. This exact time can provide readers with the background in which the event happened. In this way, it brings the reader closely into the time of the narrated world.

Another device used in realist texts is the presentation of place. It creates an impression of a real world by means of describing places in great detail. In this short story, there are many descriptions of place. For example, in part I, "It was a big, squarish frame house that had once been white, decorated with cupolas and spires and scrolled balconies in the heavily lightsome style of the seventies, set on what had once been our most select street. But garages and cotton gins had encroached and obliterated even the august names of that neighborhood; only Miss Emily's house was left, lifting its stubborn and coquettish decay above the cotton wagons and the gasoline pumps-an eyesore among eyesores". This passage shows a very vivid picture of the location of Miss Emily's building and surrounding. The detail is made more 'real' by the device of situating the narrator within view of Miss Emily's house. Faulkner acts as the 'eyes' of the reader. The purpose for using presentation of place here is to achieve the effect that readers are the members in this story.

Besides, the presentation of dialogue also plays an important role in constructing realist texts. It shows many features of oral narratives, such as speech marks, direct address between the characters, interactive question and answer questions as well as discourse markers. It is prevalent in "A Rose for Emily", for example, in part II, "A neighbor, a woman, complained to the mayor, Judge Stevens, eighty years old.

"But what will you have me do about it, madam?" he said.

"Why, send her word to stop it," the woman said. "Isn't there a law?"

"I'm sure that won't be necessary," Judge Stevens said. "It's probably just a snake or a rat that nigger of hers killed in the yard. I'll speak to him about it."

In the extract above, it is dialogue between a neighbor and the mayor, Judge Stevens. They are talking about the disgusting smell around Miss Emily's house. The conversation is presented as if it were really taking place because Faulkner uses the present tense throughout the dialogue. Also, there are interactive questions and answer sequences and report word like "said".

What's more, foregrounding is used frequently in realist writing. It is well known that foregrounding is a concept of pictorial arts, referring to that part of the composition that appears to be closest to the view (Mayer, 1969). It can help readers to understand more fully the meaning the writer is trying to create and the effect achieved. Foregrounding is achieved through deviation like metaphor and through over regularity (such as repetition, parallelism) as well as through figurative language (simile and anthropomorphic metaphor) in language use.

Firstly, as for metaphor, it is the most important type of meaning transference in literature and is linguistic process used to make comparisons between the attributes of one thing/person and something else. It is associated with a particular rule of transference which may be called the "metaphoric rule". There are three elements in a metaphor. The most generally accepted terms for the most explicitly stated elements are those introduced by I. A. Richards (1936): tenor (for the literal meaning) and vehicle (for the figurative meaning). The element that is not overtly stated is the ground 
(of comparison). Leech points out that every metaphor is implicitly of the form " $\mathrm{X}$ is like $\mathrm{Y}$ in respect of $\mathrm{Z}$ " ( $\mathrm{X}$ is the tenor, $\mathrm{Y}$ is the vehicle and $\mathrm{Z}$ is the ground) (1969: 151). For example, in this short story named "A Rose for Emily", in part I, the sentence like "WHEN Miss Emily Grierson died, our whole town went to her funeral: the men through a sort of respectful affection for a fallen monument, the women mostly out of curiosity to see the inside of her house..." is metaphor. Here, Miss Emily is the tenor, a fallen monument is the vehicle and traditional sense of hierarchy in the Old South of America is the ground. Miss Emily was referred to as a "fallen monument" in the story and She is a "monument" of Southern gentility, an ideal of past values but fallen because she has shown herself susceptible to death. This metaphor vividly reveals that Miss Emily's death signals the end of traditional system in the South of America.

Secondly, from the perspective of over regularity, repetition and parallelism are features of syntactic over regularity. The former is restricted to mean the case of exact coping of a certain previous unit in a text, such as a word, phrase or even a sentence (Leech, 1969). There are two places showing repetition in this story. One is in part I, "Her voice was dry and cold. "I have no taxes in Jefferson. Colonel Sartoris explained it to me. Perhaps one of you can gain access to the city records and satisfy yourselves."

"But we have. We are the city authorities, Miss Emily. Didn't you get a notice from the sheriff, signed by him?"

"I received a paper, yes," Miss Emily said. "Perhaps he considers himself the sheriff . . I have no taxes in Jefferson."

"But there is nothing on the books to show that, you see we must go by the-"

"See Colonel Sartoris. I have no taxes in Jefferson."

"But, Miss Emily_-"

"See Colonel Sartoris." (Colonel Sartoris had been dead almost ten years.) "I have no taxes in Jefferson. To be!" The Negro appeared. "Show these gentlemen out." The sentence like "I have no taxes in Jefferson." is repeated by four times. This sentence is said by Miss Emily when a deputation asked for her to pay taxes. The purpose of repetition here is to emphasize Miss Emily's obstinateness and she was not apt to change her idea. Miss Emily's character tragedy lies in the obstinate traditional sense of hierarchy in the Old South of America. In this way, Miss Emily's character is vividly presented. Another is in part III,

Without calling it noblesse oblige. They just said, "Poor Emily. Her kinsfolk should come to her." She had some kin in Alabama; but years ago her father had fallen out with them over the estate of old lady Wyatt, the crazy woman, and there was no communication between the two families. They had not even been represented at the funeral.

And as soon as the old people said, "Poor Emily," the whispering began. "Do you suppose it's really so?" they said to one another. "Of course it is. What else could ..." This behind their hands; rustling of craned silk and satin behind jalousies closed upon the sun of Sunday afternoon as the thin, swift clop-clop-clop of the matched team passed: "Poor Emily."
The sentence like "Poor Emily." is said by people around Miss Emily for three times. Repetition of "Poor Emily" is to show Faulkner's sympathy to Miss Emily. In addition, parallelism means exact repetition in equivalent positions. It differs from simple repetition in that it doesn't extend to absolute duplication. It "requires some variable feature of the pattern-some contrasting elements which are 'parallel' with respect to their position in the pattern" (Leech, 1969:66). According to the definition of parallelism, in this short story, it can be found in part II. "We did not say she was crazy then. We believed she had to do that. We remembered all the young men her father had driven away, and we knew that with nothing left, she would have to cling to that which had robbed her, as people will." There are four sentences in this selected passage and these four sentences are parallel. "We", as the subject, is repeated in all the four sentences. These parallel sentences emphasize the point that Faulkner wants to express his sympathy and compassion to the tragic fate of Miss Emily and create a sense of closeness between readers and his story.

In addition, figurative language is a significant element in this short story because it can increase the aesthetic effect in the text. A simile, as one of figurative languages, is a way of comparing one thing with another, of explaining what one thing is like by showing how it is similar to another thing, and it explicitly signals itself in a text, with the words as or like. In the light of the conception of simile, there are many similes in this story. For example, the sentences like "She looked bloated, like a body long submerged in motionless water, and of that pallid hue. Her eyes, lost in the fatty ridges of her face, looked like two small pieces of coal pressed into a lump of dough as they moved from one face to another while the visitors stated their errand." are two similes. The former describes Miss Emily's body that is very obesity and the latter shows her inactive eyes. The effect of her separation from the outside world is generated by means of description of Miss Emily's appearance. Also, a feeling of sympathy is produced. Another example is in part III, the sentence like "She looked back at him, erect, her face like a strained flag." is also a simile in which Miss Emily's face is regarded as a strained flag when she bought arsenic. Here, the purpose of the simile is to show her coldness to the druggist and her character is reflected vividly. At the same time, anthropomorphic metaphor is used in this story. When animals, objects, or concepts are given specifically human attributes, anthropomorphism is taken place. Writers make use of this device to create human's emotion. For example, in part I, the sentence "But garages and cotton gins had encroached and obliterated even the august names of that neighborhood;" is anthropomorphism in which the verb "encroached" means to approach or take control of something gradually or without being noticed and the verb "obliterated" means to remove all signs of something either by destroying it or by covering it so that it can not be seen. Here, Faulkner gives the human's behavior to garages and cotton gins. "Garages and cotton gins" represents the new system in America and "the august names of that neighborhood" signals the traditional system. It shows that the old system in the South of America is replaced by the new system gradually and quietly. By using anthropomorphism, the aesthetic effect is achieved. 
As for the type of text of the short story "A Rose for Emily", it is a "showing" text. Firstly, according to the conception of "showing" text, it enables the reader to be a 'consumer' of the meanings, narratives and characters which are presented to them by the text. The structures of showing texts are smooth on the outside and the language is ordinary and natural. Then, it can be seen everywhere in the short story. For example, in part I, "When the next generation, with its more modern ideas, became mayors and aldermen, this arrangement created some little dissatisfaction. On the first of the year they mailed her a tax notice. February came, and there was no reply. They wrote her a formal letter, asking her to call at the sheriff's office at her convenience. A week later the mayor wrote her himself, offering to call or to send his car for her, and received in reply a note on paper of an archaic shape, in a thin, flowing calligraphy in faded ink, to the effect that she no longer went out at all. The tax notice was also enclosed, without comment". This extract makes few demands on the reader. It is easy for readers to understand this text because the meaning is transparent in this story. It is clear that the meaning of this passage is that Miss Emily refused to pay taxes. Also, the characters are presented through third person narration. What's more, in part II, "We did not say she was crazy then. We believed she had to do that. We remembered all the young men her father had driven away, and we knew that with nothing left, she would have to cling to that which had robbed her, as people will." In this passage, Faulkner uses the first person form "we" to create a sense of closeness between readers and his story in the shared time. In this way, the voice of the narration is foregrounded and a close relationship between readers and narrator is created. Therefore, this story is a "showing" text.

\section{CONCLUSION}

Therefore, the short story "A Rose for Emily", written by William Faulkner, is the realist text. It can be analyzed according to the stylistic features of realism involved confabulation and symbolism as well as foregrounding. At the same time, the stylistic analysis provides us with another perspective to get better interpretation of the literature.

\section{REFERENCES}

[1] Emory Elliott, Columbia Literary History of the United States [M]. New York: Columbia University Press, 1988:891.

[2] F. de Saussure, Course in General Linguistics [M]. Beijing: Foreign Language Teaching and Research Press, Gerald Duckworth \& Co. Ltd, 2001:111.

[3] Annette T. Rubinstein, American Literature Root and Flower [M].Beijing: Foreign Language Teaching and Research Press, 1988: preface. 